\title{
Evaluation of Antioxidant, Antimicrobial, Cytotoxic Potential and Elemental Analysis of Filago desertorum Whole Plant
}

\author{
ABIDA BANO, NADIA MUSHTAQ ${ }^{1 *}$, M. AHMAD ${ }^{1}$ AND S. MEHMOOD \\ Department of Botany, ${ }^{1}$ Department of Biotechnology, Faculty of Biological Sciences, University of Science and Technology, \\ Bannu 28100, Pakistan
}

Mushtaq et al.: Antioxidant, Antimicrobial, Cytotoxic and Elemental Analysis of Filago desertorum

\begin{abstract}
The present study aimed to evaluate the ethanolic extract of Filago desertorum for its probable antioxidant, antimicrobial, cytotoxicity potential and to assess its elemental analysis. The ethanolic extract showed maximum 2,2-diphenyl-1-picrylhydrazyl (68.48\%), 2,2'-azino-bis-(3-ethylbenzothiazoline-6-sulfonic acid (71.32 \%) and hydrogen peroxide (69.44\%) scavenging activity as compared to ascorbic acid (reference) at the concentration of $250 \mu \mathrm{g} / \mathrm{ml}$. The maximum total antioxidant activity $(71.53 \%)$ and reducing power (0.197) were observed at a concentration of $250 \mu \mathrm{g} / \mathrm{ml}$. The extract showed maximum percent inhibition against fungal strain Aspergillus fumigates $(90 \%)$ and bacterial strain Staphylococcus aureus $(10 \mathrm{~mm})$. The maximum percent mortality $(70 \%)$ was determined at $250 \mu \mathrm{g} / \mathrm{ml}$ concentration with half maximal inhibitory concentration of $127.00 \mu \mathrm{g} / \mathrm{ml}$. Elemental analysis showed that the sodium $(92.936 \mathrm{mg} / \mathrm{ml}) \mathrm{was}$ found to be present in large amount while zinc $(0.060 \mathrm{mg} / \mathrm{g})$ was found present in low concentration but cobalt was not detected. Based on the current results, it can be concluded that Filago desertorum has maximum inhibitory, antimicrobial, cytotoxic potential and therefore can lead to antioxidant, anticancer and antibiotics agents.
\end{abstract}

Key words: Hydrogen peroxide, Artemia salina, Staphylococcus aureus and Aspergillus fumigates

Regardless of unbelievable advancement in synthetic medicines, plants build a significant contribution to the pharmaceutical industries ${ }^{[1]}$. Plants based medicinal products are gaining attention by the researchers because they are harmless, simply accessible, profitable, adequate and are a promising source of the presence of valuable minerals ${ }^{[2]}$. Many pharmaceutical companies in Pakistan are researching medicinal plants to explore their therapeutic potential for designing new drugs. Plant based natural products are either pure composites or crude extract. Herbalists though believe that the influence of a plant lies in the interaction of all its constituents ${ }^{[3]}$. According to the World Health Organization (WHO), $80 \%$ of people of the world depend on crude plant extract and their active constituents to maintain their primary health and to treat many diseases ${ }^{[4,5]}$. Various reports have demonstrated the plant based natural products as potential scavengers of numerous free radicals ${ }^{[6]}$, therefore, the researchers are making efforts to obtain plant based antioxidants which have no or fewer side effects. The antioxidant

*Address for correspondence

E-mail: nadiabnu@yahoo.com

November-December 2021 is a compound that can retard the oxidation of macromolecules or restrain the cell damage done by reactive oxygen species ${ }^{[7]}$. Most of the active antioxidant ingredients are flavonoids, anthocyanins, flavones, isoflavones, catechins, coumarins, lignans and isocatechins ${ }^{[8]}$. The antioxidants reduce the oxidative stress by either inhibition of free radical's production or by increasing the antioxidant defence ${ }^{[9]}$.

The plant extract has been used traditionally to cure several contagious diseases caused by protozoa, bacteria, viruses and fungi ${ }^{[10]}$. The substances that may either restrain the development of bacteria or destroy them are thought to be a good source for designing and developing new antimicrobial drugs ${ }^{[11]}$. Several reports

This is an open access article distributed under the terms of the Creative
Commons Attribution-NonCommercial-ShareAlike 3.0 License, which
allows others to remix, tweak, and build upon the work non-commercially,
as long as the author is credited and the new creations are licensed under
the identical terms Accepted 01 September 2021 Revised 14 June 2021 Received 18 January 2020 Indian J Pharm Sci 2021;83(6):1243-1253 
are available showing in vivo and in vitro efficiency of plant extract against human, animal and plant microbes that result in the initiation of infections ${ }^{[12]}$. A few synthetic drugs are approved for the treatment of many diseases in plant and human, however, currently, the use of some plant derived products has been emerged to cut back the spread of causative microorganisms ${ }^{[13]}$.

Trace elements have a therapeutic and restorative role against different diseases ${ }^{[14]}$. Mineral rudiments through constructing a bit quantity of entire chemical composition and mass of the body of the plant materials, however, their anatomical significance cannot be neglected in medicine activities and metabolic system $^{[15]}$.

The Artemia salina lethality analysis was thought to be an acceptable model for introductory recognition of antitumor and toxicant activity ${ }^{[16]}$. The Artemia salina evaluation is very helpful for the separation of essential composites from the plant against cancer ${ }^{[17]}$.

Filago desertorum (F. desertorum) belong to family Composite. It is a commonly wild annual desert plant that grows in sand and prefers sunny or semi-shady places for its growth. This plant is distributed in Canary Island, Southwest Asia and Southern Spain to North Africa through the Middle East to Afghanistan, Pakistan and India ${ }^{[18]}$.

\section{MATERIALS AND METHODS}

\section{Plant collection, identification and extract preparation:}

The $F$. desertorum plant specimen was collected from a remote region of Bannu District. The plant was identified and authenticated by Professor Dr. Abdu-urRehman at the Department of Botany, Government Post Graduate College Bannu and the Voucher specimens were deposited in the herbarium of Department of Botany University of Science and Technology Bannu Laboratory under the number Fd-F-1. The collected plant samples were carefully washed by tap water followed by distilled water and was dried under shade. The dried whole plant material (roost, leaves, shoots, stem, fruit and flower) was ground into a fine powder by electric mixing and stored for further use in an airtight jar. The fine powder (50 g) of whole (roost, leaves, shoots, stem, fruits and flowers) plant was soaked in $500 \mathrm{ml}$ ethanol in a conical flask for fifteen days while shaking occasionally. The filtrate solution was concentrated at $15^{\circ}$ and high pressure by rotary evaporator. The material obtained was permitted to dry at room temperature and was stored in a refrigerator for further several activities.

\section{In vitro antioxidant assays:}

2,2-diphenyl-1-picrylhydrazyl (DPPH) radical scavenging activity assay: The DPPH free radical inhibition activity was done following a standard procedure ${ }^{[19]}$. Stock solution of DPPH was prepared by dissolving $3 \mathrm{mg}$ DPPH in $100 \mathrm{ml}$ ethanol and then stored at $20^{\circ}$. The solution was further diluted with ethanol with absorbance range between 1-0.4 at $517 \mathrm{~nm}$ by spectrophotometer. Plant extract and Ascorbic acid stock solution preparation: $5 \mathrm{mg}$ plant extract and Ascorbic acid were separately dissolved in $5 \mathrm{ml}$ ethanol. Preparation of various concentrations by $\mathrm{C}_{1} \mathrm{~V}_{1}=\mathrm{C}_{2} \mathrm{~V}_{2}$ : To prepare $50 \mu \mathrm{g} / \mathrm{ml}$ concentrations, pipette out $50 \mu \mathrm{l}$ from the stock solution $(5 \mathrm{mg} / 5 \mathrm{ml})$ by micropipette and mixed with $950 \mu 1$ ethanol. Similarly, do for 100, 150, 200 and $250 \mu \mathrm{g} / \mathrm{ml}$. Ethanolic DPPH solution was used as a control. $200 \mu \mathrm{l}$ extract of $F$. desertorum at different concentration $(50 \mu \mathrm{g} / \mathrm{ml}$ $-250 \mu \mathrm{g} / \mathrm{ml}$ ) and $2 \mathrm{ml} \mathrm{DPPH}$ solution was added in a test tube and reserved in the dark at room temperature for $20 \mathrm{~min}$ and absorbance was taken at $517 \mathrm{~nm}$ spectrophotometer (SP-300 Japan). The experiment was performed in triplicates while Ascorbic acid was taken as standard. The percent inhibition was measured by the following equation:

Scavenging (percentage) inhibition $=[$ (control-test sample $) /($ control $)] \times 100$

\section{2,2'-Azino-Bis-3-Ethylbenzothiazoline-6-Sulfonic} Acid (ABTS) radical scavenging assay: ABTS inhibition activity was evaluated by standard procedure $^{[20]}$. Stock solution of ABTS was prepared by mixing ABTS $(7 \mathrm{mM})$ with potassium persulfate solution $(2.45 \mathrm{mM})$ and was kept in a dark for $24 \mathrm{~h}$ to produce a dark colored solution. The ABTS solution was further diluted by ethanol to obtain an absorbance $(<1$ and $>0.4)$ at $745 \mathrm{~nm}$ using the spectrophotometer. Plant extract and Ascorbic acid stock solution preparation: $5 \mathrm{mg}$ plant extract and Ascorbic acid were separately dissolved in $5 \mathrm{ml}$ ethanol. Preparation of various concentrations by $\mathrm{C}_{1} \mathrm{~V}_{1}=\mathrm{C}_{2} \mathrm{~V}_{2}$ : To prepare $50 \mu \mathrm{g} / \mathrm{ml}$ concentrations, pipette out $50 \mu \mathrm{l}$ from the stock solution $(5 \mathrm{mg} / 5 \mathrm{ml})$ by micropipette and mixed with $950 \mu \mathrm{l}$ ethanol. Similarly, do for 100, 150, 200 and $250 \mu \mathrm{g} / \mathrm{ml}$. Ethanolic ABTS solution was used as a control. ABTS inhibition capability was estimated by mixing $200 \mu \mathrm{l}$ of extract $(50 \mu \mathrm{g} / \mathrm{ml}-250 \mu \mathrm{g} / \mathrm{ml})$ at varying concentrations with $2 \mathrm{ml}$ of ABTS solution 
in test tubes and incubated for 6 min. After 6 min the absorbance was taken at $745 \mathrm{~nm}$. The experiment was performed thrice.

Phosphomolybdate (PMA) assay (total antioxidant assay): Todetermine the PMA, the phosphomolybdenum modified method ${ }^{[21]}$ was used. Plant extract and Ascorbic acid stock solution preparation: $5 \mathrm{mg}$ plant extract and Ascorbic acid were separately dissolved in $5 \mathrm{ml}$ ethanol. Preparation of various concentrations by $\mathrm{C}_{1} \mathrm{~V}_{1}=\mathrm{C}_{2} \mathrm{~V}_{2}$ : To prepare $50 \mu \mathrm{g} / \mathrm{ml}$ concentrations, pipette out $50 \mu \mathrm{l}$ from the stock solution $(5 \mathrm{mg} / 5 \mathrm{ml})$ by micropipette and mixed with $950 \mu 1$ ethanol. Similarly, do for $100,150,200$ and $250 \mu \mathrm{g} / \mathrm{ml}$. Briefly, $0.1 \mathrm{ml}$ of different concentrations ( $50 \mu \mathrm{g} / \mathrm{ml}$ to $250 \mu \mathrm{g} / \mathrm{ml})$ of plant extract was mixed with $1 \mathrm{ml}$ of reagent solution (0.6 M sulphuric acid, $28 \mathrm{mM}$ sodium phosphate and $4 \mathrm{mM}$ ammonium molybdate) in a test tube, capped with aluminium foil and incubated at $95^{\circ}$ in a water bath for $30 \mathrm{~min}$. Against blank, the absorbance of the mixture was measured at $765 \mathrm{~nm}$. Ascorbic acid was used as standard. The assay was performed in triplicates.

Hydrogen Peroxide $\left(\mathrm{H}_{2} \mathrm{O}_{2}\right)$ scavenging assay: $50 \mathrm{mM}$ $\mathrm{H}_{2} \mathrm{O}_{2}$ solution was prepared in phosphate buffer $(50 \mathrm{mM}$, $\mathrm{pH}$ 7.4). Plant extract and Ascorbic acid stock solution preparation: $5 \mathrm{mg}$ plant extract and Ascorbic acid were separately dissolved in $5 \mathrm{ml}$ ethanol. Preparation of various concentrations by $\mathrm{C}_{1} \mathrm{~V}_{1}=\mathrm{C}_{2} \mathrm{~V}_{2}$ : To prepare $50 \mu \mathrm{g} / \mathrm{ml}$ concentrations, pipette out $50 \mu \mathrm{l}$ from the stock solution $(5 \mathrm{mg} / 5 \mathrm{ml})$ by micropipette and mixed with $950 \mu 1$ ethanol. Similarly, do for 100, 150, 200 and $250 \mu \mathrm{g} / \mathrm{ml}$. Briefly, $1.5 \mathrm{ml}$ of extract solution at different concentrations $(50-250 \mu \mathrm{g} / \mathrm{ml})$ was added to $0.6 \mathrm{ml}$ of hydrogen peroxide solution in a silver foil capped test tube and incubated for $15 \mathrm{~min}$. After incubation, the absorbance was recorded at $230 \mathrm{~nm}$ against a blank solution. Ascorbic acid was used as a standard. The experiment was performed three times ${ }^{[22]}$.

Reducing power assay: Plant extract and Ascorbic acid stock solution preparation: $5 \mathrm{mg}$ plant extract and Ascorbic acid were separately dissolved in $5 \mathrm{ml}$ ethanol. Preparation of various concentrations by $\mathrm{C}_{1} \mathrm{~V}_{1}=\mathrm{C}_{2} \mathrm{~V}_{2}$ : To prepare $50 \mu \mathrm{g} / \mathrm{ml}$ concentrations, pipette out $50 \mu 1$ from the stock solution $(5 \mathrm{mg} / 5 \mathrm{ml})$ by micropipette and mixed with $950 \mu 1$ ethanol. Similarly, do for 100 , 150,200 and $250 \mu \mathrm{g} / \mathrm{ml} .500 \mu 1$ potassium ferricyanide (10 mg/ml), $500 \mu \mathrm{l}$ phosphate buffer $(0.2 \mathrm{M}, \mathrm{pH} 6.6)$ and $500 \mu \mathrm{l}$ extract from concentrations $(50 \mu \mathrm{g} / \mathrm{ml}$ to $250 \mu \mathrm{g} / \mathrm{ml}$ ) were mixed and incubated at $60^{\circ}$ for $30 \mathrm{~min}$ in a water bath and then added $500 \mu 1$ trichloroacetic acid $(0.1 \mathrm{~g} / \mathrm{l}) .1 \mathrm{ml}$ from the above solution was mixed with $1 \mathrm{ml}$ of Distilled Water (D. $\mathrm{H}_{2} \mathrm{O}$ ) and $0.2 \mathrm{ml}$ of $0.1 \%(\mathrm{w} / \mathrm{v})$ ferric chloride in a tube and incubated for $15 \mathrm{~min}$. After $15 \mathrm{~min}$ reaction, the absorbance was taken at $700 \mathrm{~nm}$. The absorbance of the reaction solution increases with the increase of concentrations shows a high reducing power. The experiment was performed 3 times $^{[23]}$.

\section{In vitro antimicrobial assay:}

Antibacterial assay: Various concentrations of $F$. desertorum extract were screened by applying agar well diffusion method ${ }^{[24]}$ with some modifications against Staphylococcus aureus, Proteus vulgarus, Micrococcus luteus and Klebsiella pneumonia. Briefly, nutrient agar plates were prepared and incubated for $24 \mathrm{~h}$ for the aseptic test. On the sterile nutrient agar plates, $24 \mathrm{~h}$ old culture from the nutrient broth was spread on it by sterile cotton swab to make a bacterial lawn. Six wells were made in each plate using a sterile $6 \mathrm{~mm}$ cork borer. From the extract $(10 \mathrm{mg} / \mathrm{ml}, 20 \mathrm{mg} / \mathrm{ml}$, $30 \mathrm{mg} / \mathrm{ml}$ and $40 \mathrm{mg} / \mathrm{ml}$ ), Dimethyl Sulfoxide (DMSO) and Levofloxacin $100 \mu 1$ was added to the respective well and incubated at $37^{\circ}$ for $24 \mathrm{~h}$. In this assay, DMSO solvent was used as a vehicle control. After $24 \mathrm{~h}$ the inhibition zone was measured in comparison with positive control in $\mathrm{mm}$. Levofloxacin was used as a positive control (reference).

Antifungal assay: The screening of different concentrations of ethanolic extract for antifungal activity was evaluated by the tube dilution method ${ }^{[25]}$ with modifications. Sabouraud Dextrose Agar (SDA) medium was prepared by dissolving it in distilled water and then stirred with a magnetic stirrer until complete dissolution. $5 \mathrm{ml}$ media was added to the respective test tubes and then autoclaved at $121^{\circ}$ for 15 min using a moist steam sterilization method. After sterilization $67 \mu \mathrm{l}$ of DMSO extract (10, 20 and $30 \mathrm{mg} /$ $\mathrm{ml}$ ) and terbinafine were added to the non-solidified test tubes. The tubes were then allowed to solidify in a slanting position at room temperature. Each tube was inoculated with a $4 \mathrm{~mm}$ diameter piece of inoculums removed from a 5 or $7 \mathrm{~d}$ old culture of fungi. All test tubes were incubated for $5-7 \mathrm{~d}$ at $28-30^{\circ}$ temperature. Humidity ( $40 \%$ to $50 \%$ ) was controlled by placing an open pan of water in the incubator. Terbinafine was used as a standard (reference). DMSO was used as vehicle control in this experiment. On $d 7$, the visible non-mycelia linear growth inhibitions of fungal species were examined in comparison to the drug. 
Elemental analysis: For elemental analysis, the standard protocol ${ }^{[26]}$ was used to prepare the sample by wet digestion method. $1 \mathrm{~g}$ plant powder mixed with $10 \mathrm{ml}$ nitric acid (67\%) and was kept for $24 \mathrm{~h}$ at room temperature. $4 \mathrm{ml}$ perchloric acid $(67 \%)$ was added to the above mixture and kept for $30 \mathrm{~min}$ and then heated at $60^{\circ}$ on hot plates to obtained $1 \mathrm{ml}$ apparent solution.

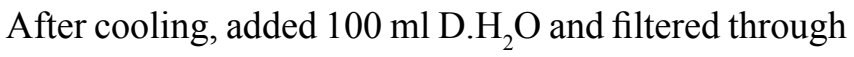
Whatman \# 42 filter paper and was stored for elemental analysis in airtight bottles ${ }^{[27]}$. This filtrate solution was used as a stock solution. To analyze the sample in triplicate advanced technology instruments were used such as flame atomic absorption spectrophotometer (Polarized Zeeman Hitachi 2000), flame photometer (Jenway PFP7, UK). A stock solution of each metal was further diluted for standard calibrations ${ }^{[28]}$.

\section{In vitro cytotoxic assay:}

Cytotoxic activity of the extract was assessed following the standard procedure ${ }^{[29]}$ with some modifications. $5 \mathrm{mg}$ plant extract and Ascorbic acid were separately dissolved in $5 \mathrm{ml}$ ethanol. Preparation of various concentrations by $\mathrm{C}_{1} \mathrm{~V}_{1}=\mathrm{C}_{2} \mathrm{~V}_{2}$ : To prepare $50 \mu \mathrm{g} /$ $\mathrm{ml}$ concentrations, pipette out $50 \mu 1$ from the stock solution $(5 \mathrm{mg} / 5 \mathrm{ml})$ by micropipette and mixed with $950 \mu 1$ ethanol. Similarly, do for 100, 150, 200 and $250 \mu \mathrm{g} / \mathrm{ml} .2 .8 \mathrm{~g}$ ocean salt (Sigma) was dissolved in D. $\mathrm{H}_{2} \mathrm{O}(100 \mathrm{ml})$ with continues mixing for $2 \mathrm{~h}$. Regarding two grams of Artemia salina eggs was aerated during 11 capability beaker instrumentally (separating funnel) containing ocean salt resolution. Once $24 \mathrm{~h}$ of incubation at room temperature $\left(25-29^{\circ}\right)$, using continuous lighting of visible radiation lamp, pink-colored small larvae were hatched. $0.5 \mathrm{ml}$ from various concentrations was taken in the test tubes. These test tubes were allowed for entire vaporization of solvent (ethanol) at $45^{\circ}$ for $24 \mathrm{~h}$. Once the entire solvent (ethanol) was vaporized then $3 \mathrm{ml}$ saline (ocean salt) was poured in each tube. $3 \mathrm{ml}$ saline solution was taken within the separating tubing for control. 10 live brine shrimps were added to each tube and then the setup could stay for $24 \mathrm{~h}$. The experiment was performed in triplicates. The survival larvae were counted after $24 \mathrm{~h}$. Once after $24 \mathrm{~h}$ the percent mortality was computed by the subsequent equation.

Percentage Mortality=Survival in control-Survival in test/Survival in control $\times 100$

\section{Statistical analysis:}

The data were expressed as the mean \pm standard deviation of three replications. The analysis was performed using statistics 9.0 software. One-way Analysis of Variance (ANOVA) and the least significant difference test was used to evaluate the possible difference among the means at $\mathrm{p}<0.05$. The $50 \%$ inhibition was calculated by linear regression analysis in Microsoft Excel 2007. The Lethal Concentration $50 \%\left(\mathrm{LC}_{50}\right)$ value at $95 \%$ confidence interval was determined after $24 \mathrm{~h}$ using the probit analysis method ${ }^{[30]}$.

\section{RESULTS AND DISCUSSION}

DPPH radical scavenging activity of various concentrations of an extract of $F$. desertorum was

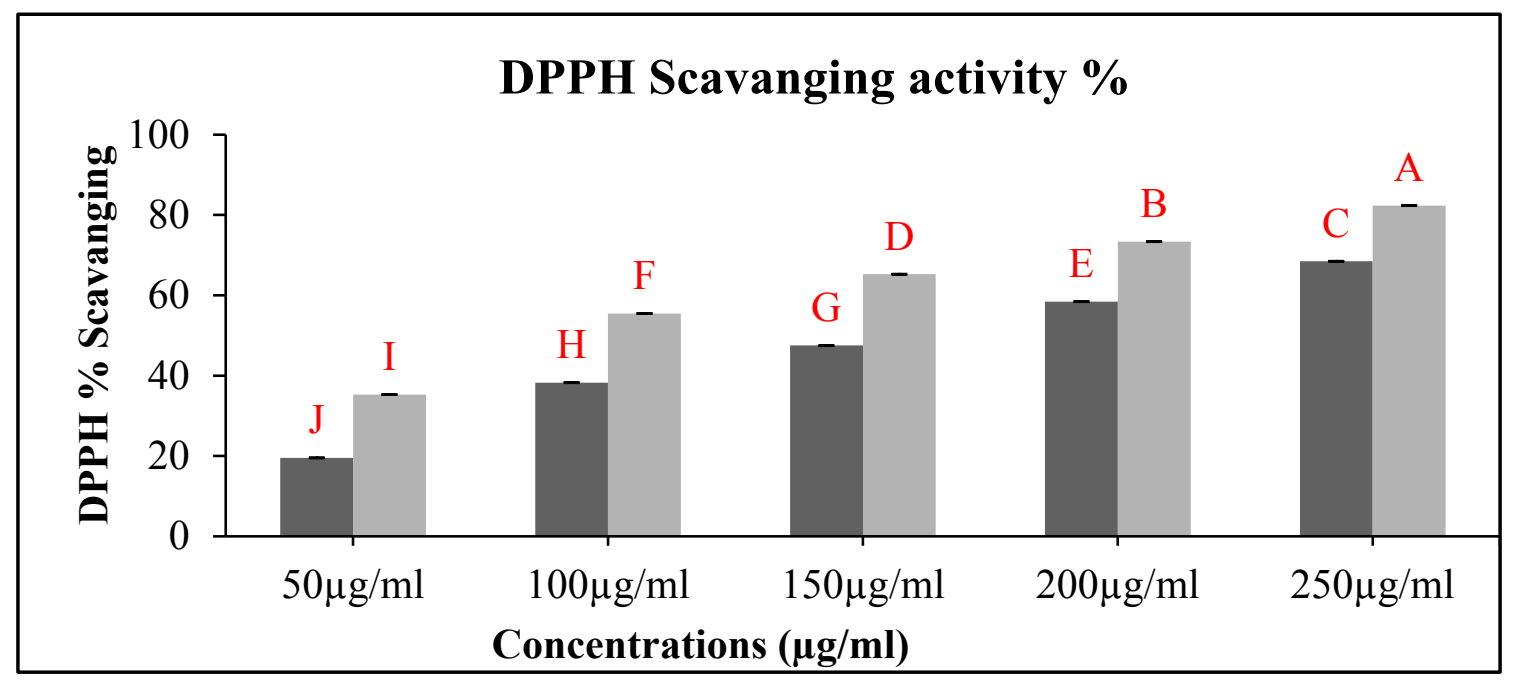

Fig 1: DPPH radical scavenging activity of $F$. desertorum and Ascorbic acid. The data shown are the percent inhibitions of three replicates with standard deviation indicated by vertical bars. The bars designed by different letters indicate significantly differences between the means of $F$. desertorum extract and standard (Ascorbic acid) concentrations at $p<0.05$. One way ANOVA followed by least significant difference comparisons $(\mathrm{LSD}=\mathbf{0 . 2 0 4 4 )}$ ) test was performed to analysis this data, ( $)$ : $F$. desertorum extract; ( ): Ascorbic acid 
denoted in fig. 1. All concentrations showed different levels of DPPH radical scavenging activity over the range of $50-250 \mu \mathrm{g} / \mathrm{ml}$ and Half-Maximal Inhibitory Concentration $\left(\mathrm{IC}_{50}\right.$ ) value was found to be $165.12 \mu \mathrm{g} /$ $\mathrm{ml}$ respectively. $250 \mu \mathrm{g} / \mathrm{ml}$ concentration exhibited maximum DPPH radical scavenging activity as compared to other concentrations. The extract radical scavenging activity was effective in the order $250 \mu \mathrm{g} / \mathrm{ml}>200 \mu \mathrm{g} / \mathrm{ml}>150 \mu \mathrm{g} / \mathrm{ml}>100 \mu \mathrm{g} / \mathrm{ml}>50 \mu \mathrm{g} /$ $\mathrm{ml}$. Ascorbic acid was used as standards at concentration of $50-250 \mu \mathrm{g} / \mathrm{ml}$ and the $\mathrm{IC}_{50}$ value was found to be $95.29 \mu \mathrm{g} / \mathrm{ml}$ respectively. Standard and plant extract showed a dose dependent inhibition of DPPH radicals. The low $\mathrm{IC}_{50}$ value is indicative of high DPPH inhibitory activity. The $F$. desertorum extract and standard (Ascorbic acid) concentrations showed a significant difference $(\mathrm{p}<0.05)$ in DPPH scavenging activity.

The $F$. desertorum extract showed maximum ABTS radicals scavenging activity (fig. 2). There was a steady increase in the percentage inhibition of the ABTS radicals by the $F$. desertorum extract and maximum inhibition was achieved above $250 \mu \mathrm{g} / \mathrm{ml}$ of extract. $F$. desertorum extract $\left(\mathrm{IC}_{50}, 147.21 \mu \mathrm{g} / \mathrm{ml}\right)$ was less active than standard Ascorbic acid $\left(\mathrm{IC}_{50}, 97.35 \mu \mathrm{g} /\right.$ $\mathrm{ml}$ ) and was significantly different from Ascorbic acid $(\mathrm{p}>0.05)$. The F. desertorum extract showed a percentage inhibition of less than $80 \%$ at the highest concentration $(250 \mu \mathrm{g} / \mathrm{ml})$. Significant $(\mathrm{p}<0.05)$ scavenging of ABTS radicals were evident at all the tested concentrations of $F$. desertorum extract and standard (Ascorbic acid) compounds $(50-250 \mu \mathrm{g} / \mathrm{ml})$.

In the presence of extract, molybdenum (VI) is reduced to molybdenum (V) and forms a green-coloured phosphomolybdenum $\mathrm{V}$ complex, which shows maximum absorbance at $765 \mathrm{~nm}$. Fig. 3 depicts the total antioxidant capacity of different concentrations of ethanol extract of $F$. desertorum that can be ranked in the order of $250 \mu \mathrm{g} / \mathrm{ml}>200 \mu \mathrm{g} / \mathrm{ml}>150 \mu \mathrm{g} / \mathrm{ml}$ $>100 \mu \mathrm{g} / \mathrm{ml}>50 \mu \mathrm{g} / \mathrm{ml}$. The $\mathrm{IC}_{50}$ value of antioxidant capacity for the plant extract was $107.02 \mu \mathrm{g} / \mathrm{ml}$, while for the Ascorbic acid was $52.82 \mu \mathrm{g} / \mathrm{ml}$, respectively (Table 1). The obtained result show that the $250 \mu \mathrm{g} / \mathrm{ml}$ extract concentration has the notable antioxidant ability as compared to standard (Ascorbic acid) antioxidant seems to open a possibility for the exploitation of costeffective natural antioxidants. The $F$. desertorum extract and standard (Ascorbic acid) concentrations showed a significant difference $(\mathrm{p}<0.05)$ in total antioxidant capacity.

The scavenging ability of $F$. desertorum and ascorbic acid are shown in (fig. 4). $\mathrm{H}_{2} \mathrm{O}_{2}$ radical scavenging ability of extract of $F$. desertorum and ascorbic acid at concentration of $250 \mu \mathrm{g} / \mathrm{ml}$ were $69.44 \%$ and $85.55 \%$ respectively. The $\mathrm{IC}_{50}$ values of $F$. desertorum and ascorbic acid were found to be $137.76 \mu \mathrm{g} / \mathrm{ml}$ and $87.93 \mu \mathrm{g} / \mathrm{ml}$ respectively. The $\mathrm{IC}_{50}$ value indicated that plant extract is a better hydroxyl radical scavenger, which quite comparable with the standard Ascorbic acid (Table 1). In our study, the hydroxyl radical scavenging activity was increased with the increase of extract concentration. The $F$. desertorum extract and standard (Ascorbic acid) concentrations were not showed significant difference $(\mathrm{p}<0.05)$ in $\mathrm{H}_{2} \mathrm{O}_{2}$ scavenging activity.

Fig. 5 represents the reductive capabilities of various extract concentrations of $F$. desertorum. Like antioxidant

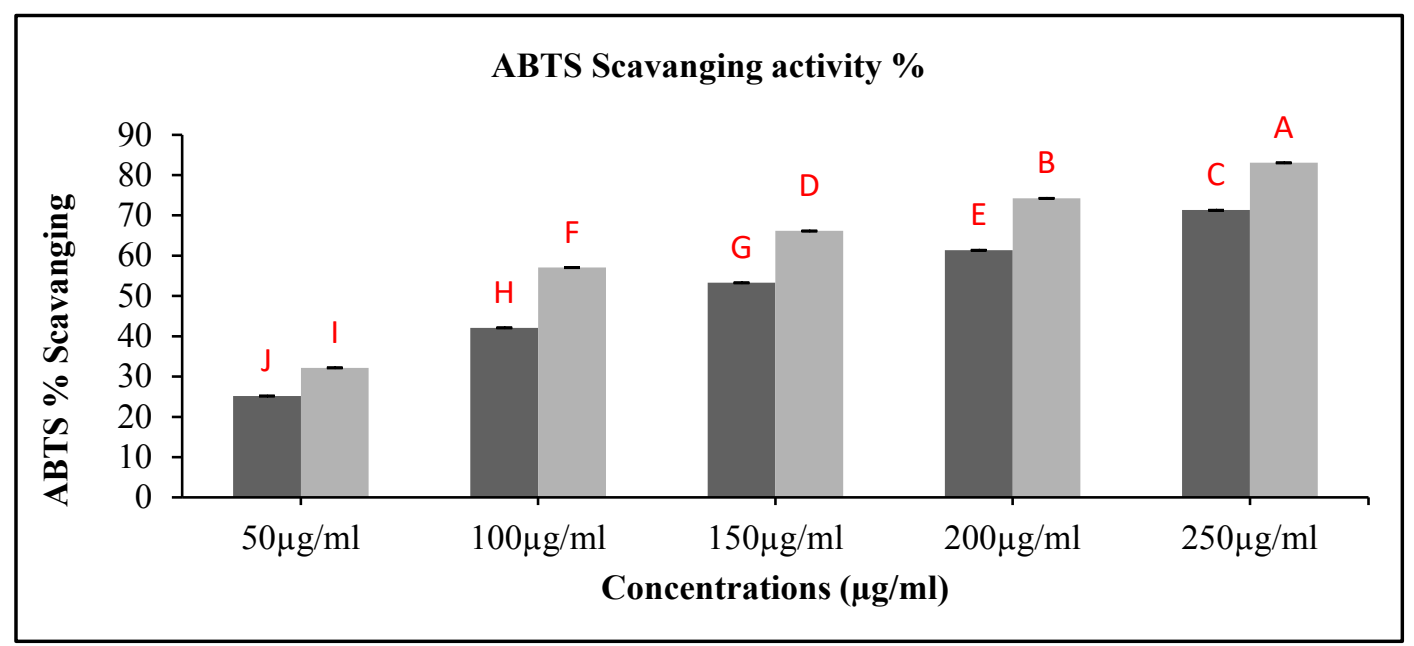

Fig 2: ABTS inhibition activity of $F$. desertorum and Ascorbic acid. The data shown are the percent inhibition of three replicates with standard deviation indicated by vertical bars. The bars designed by different letters indicate significant differences between the means of $F$. desertorum extract and standard (Ascorbic acid) concentrations at $p<0.05$. One way ANOVA followed by least significant difference comparisons $(L S D=0.2386)$ test was performed to analyze this data, $(\square)$ :F. desertorum extract; $(\square)$ : Ascorbic acid 


\section{Phosphomolybdate Scavanging activity \%}

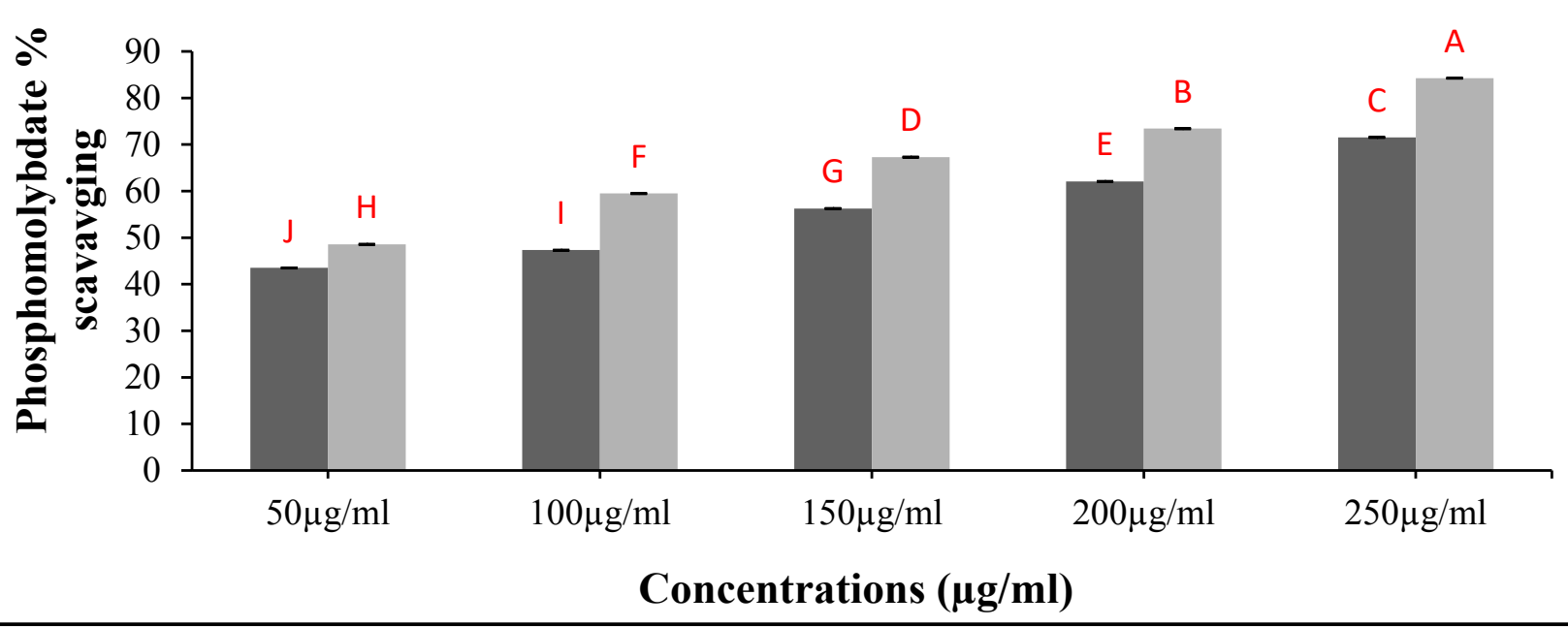

Fig. 3: Phosphomolybdate scavenging activity of $F$. desertorum and Ascorbic acid. The data shown are the percent inhibitions of three replicates with standard deviation indicated by vertical bars. The bars designed by different letters indicate significant differences between the means of $\boldsymbol{F}$. desertorum extract and standard (Ascorbic acid) concentrations at $\mathbf{p}<0.05$. One way ANOVA followed by least significant difference comparisons $(\mathrm{LSD}=\mathbf{0 . 0 8 7 1})$ test was performed to analyze this data, $(\square)$ :Filago desertorum extract; $(\square)$ : Ascorbic acid

TABLE 1: ANTIOXIDANT EFFECT (IC ${ }_{50}$ ) ON DPPH RADICALS, ABTS RADICAL, PHOSPHOMOLYBDATE SCAVENGING CAPACITY AND HYDROGEN PEROXIDE RADICAL OF ETHANOL EXTRACT $F$. desertorum AND ASCORBIC ACID

\begin{tabular}{lcccc}
\hline & \multicolumn{4}{c}{$\mathrm{IC}_{50} \mu \mathrm{g} / \mathrm{ml}$} \\
\cline { 2 - 5 } Test samples & $\begin{array}{c}\text { Scavenging ability on } \\
\text { DPPH radicals }\end{array}$ & $\begin{array}{c}\text { ABTS radical } \\
\text { scavenging activity }\end{array}$ & $\begin{array}{c}\text { Phosphomolybdate } \\
\text { scavenging capacity }\end{array}$ & $\begin{array}{c}\text { Hydrogen peroxide } \\
\text { radical scavenging } \\
\text { activity }\end{array}$ \\
\hline F. desertorum Extract & 165.12 & 147.21 & 107.02 & 137.76 \\
Ascorbic acid & 95.29 & 97.35 & 52.82 & 87.93 \\
\hline
\end{tabular}

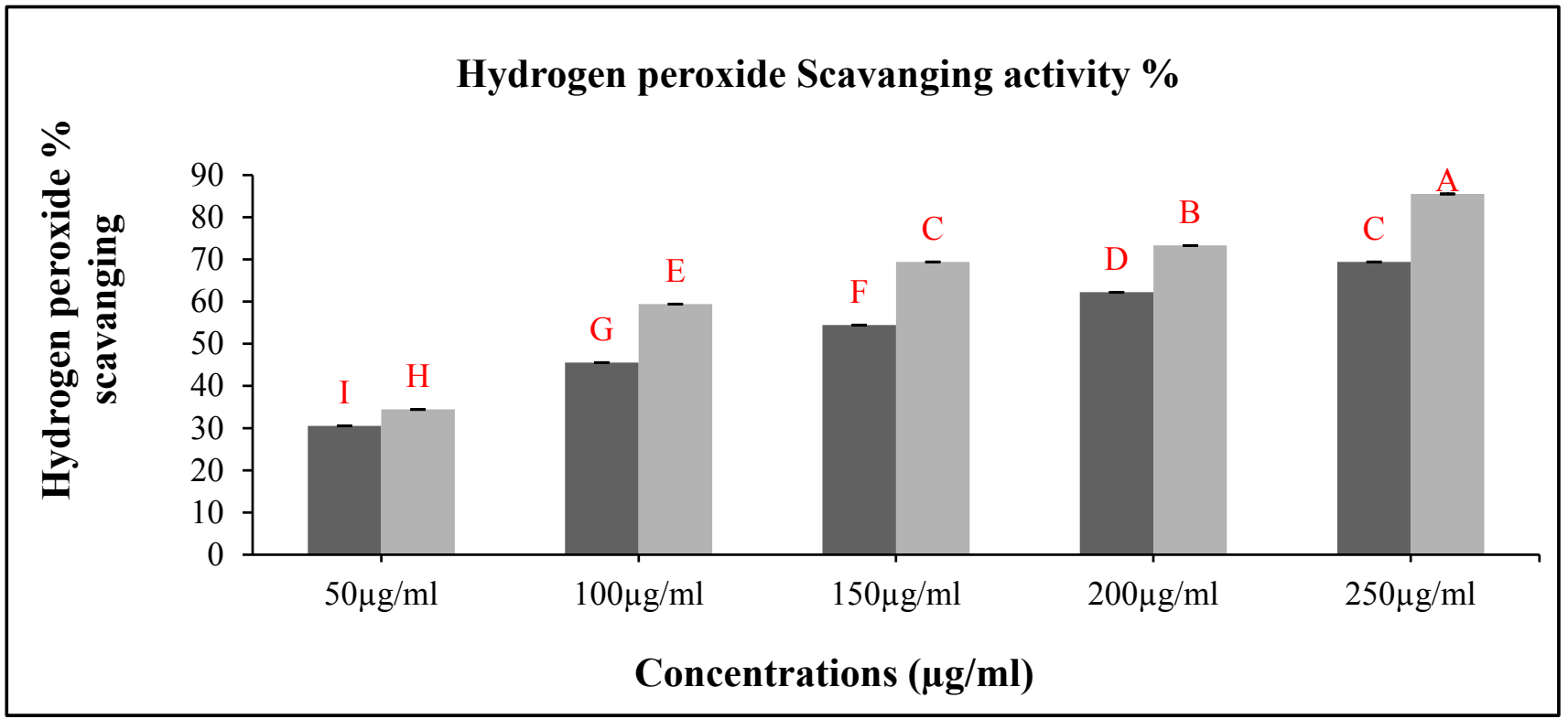

Fig 4: Hydrogen peroxide inhibition activity of $F$. desertorum and Ascorbic acid. The data shown are the percent inhibitions of three replicates with standard deviation indicated by vertical bars. The bars designed by the same letters indicate that there are no significant differences between the means of $F$. desertorum extract and standard (Ascorbic acid) concentrations at $p<0.05$. One way ANOVA followed by least significant difference comparisons test $(\mathrm{LSD}=\mathbf{0 . 9 4 7 0}$ ) was performed to analyze this data, $(\square)$ : F. desertorum extract; $(\quad)$ : Ascorbic acid 
activity, the reducing power of the extract increases with the increase in concentration. When compared to other concentrations $250 \mu \mathrm{g} / \mathrm{ml}$ exhibited highest reducing power ability. Reducing power ability of the five extract concentrations was found to increase in the order $250 \mu \mathrm{g} / \mathrm{ml}>200 \quad \mu \mathrm{g} / \mathrm{ml}>150 \quad \mu \mathrm{g} / \mathrm{ml}>100 \quad \mu \mathrm{g} / \mathrm{ml}$ $>50 \mu \mathrm{g} / \mathrm{ml}$. The extracts showed good reducing power ability in a dose dependent manner which was comparable to that of standard (Ascorbic acid). The antioxidant principles present in the extract $F$. desertorum caused the reduction of ferric ion/ferricyanide complex to the ferrous form and thus proved the reducing power ability. F. desertorum extract (0.197) was less active than Ascorbic acid (0.265) and was not significantly different from Ascorbic acid $(p>0.05)$. Increasing absorbance indicates an increase in reductive ability.

The results of these experiments revealed that crude ethanolic extract of $F$. desertorum exhibited remarkable antibacterial activities against both Gram-negative (Staphylococcus aureus and Micrococcus luteus) and Gram-positive bacteria (Klebsiella pneumonia and
Proteus vulgaris) at a concentration of $10-40 \mathrm{mg} / \mathrm{ml}$ (Table 2). Zones of inhibition ranged from $4-10 \mathrm{~mm}$ for the ethanol extract. The highest activity with an Inhibition Zone Diameter (IZD) of $10 \mathrm{~mm}$ was against Staphylococcus aureus and the least antibacterial activity was against Proteus vulgaris with the zone of inhibition of $6 \mathrm{~mm}$ diameter. The antibiotic Levofloxacin (broad spectrum antibiotic) yielded zones of inhibition that ranged between $10-25 \mathrm{~mm}$ respectively.

Different Ethanolic extract concentrations $(10 \mathrm{mg} /$ $\mathrm{ml}, 20 \mathrm{mg} / \mathrm{ml}$ and $30 \mathrm{mg} / \mathrm{ml}$ ) of $F$. desertorum were tested for their efficacy against Aspergillus fumigates, Aspergillus flavus and Aspergillus niger. All extract concentrations were found to inhibit the growth of selected fungi. Zones of growth percent inhibition ranged from $20-90 \%$ for the ethanolic extract. The extract showed maximum growth percent inhibition against Aspergillus fumigates (90\%) and minimum against Aspergillus niger (70 \%) at the concentration of $30 \mathrm{mg} / \mathrm{ml}$ (Table 3). Terbinafine (positive control) showed $100 \%$ growth inhibition.

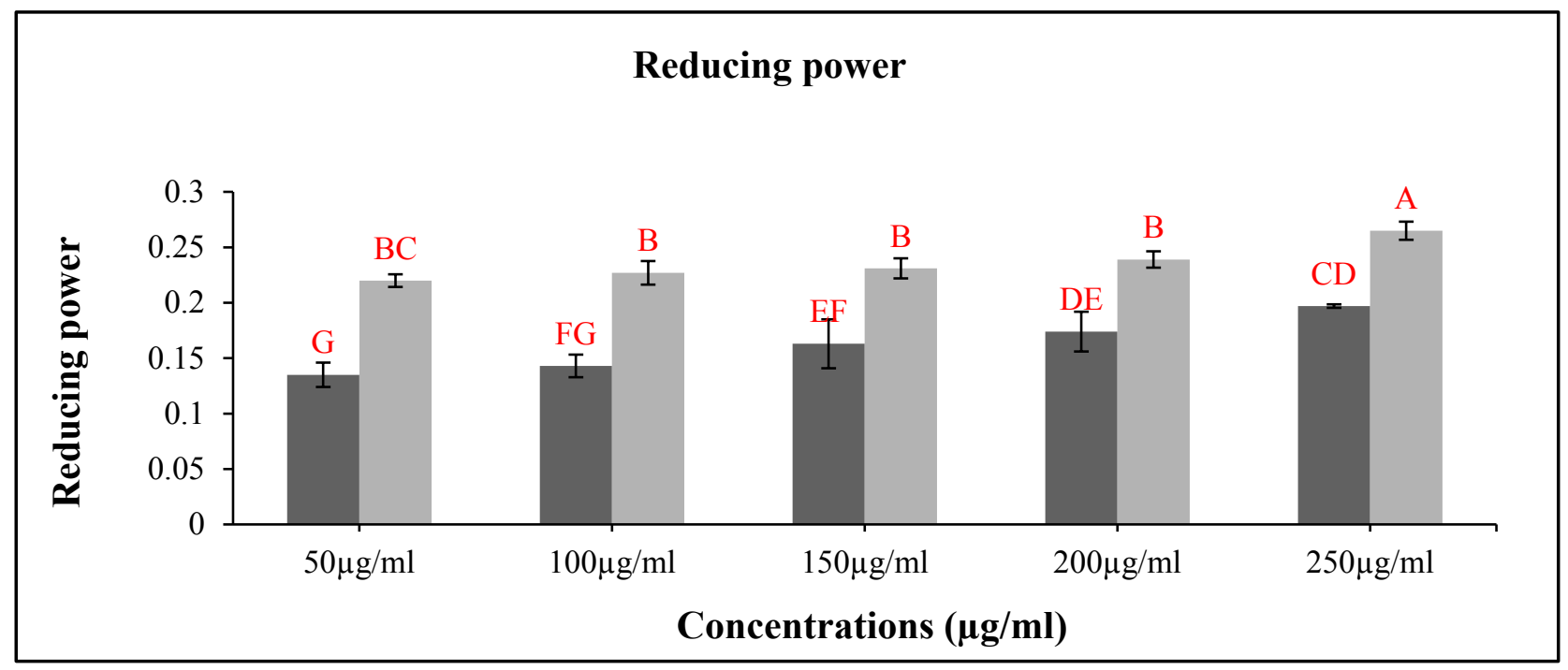

Fig. 5: Reducing power activity of $F$. desertorum and Ascorbic acid. The data shown are the percent inhibition of three replicates with standard deviation indicated by vertical bars. The bars designed by the same letters indicate that there are no significant differences between the means of $\boldsymbol{F}$. desertorum extract and standard (Ascorbic acid) concentrations at $p<0.05$. One way ANOVA followed by least significant difference comparisons (LSD=0.0245) test was performed to analyze this data, ( $\square$ ): $F$. desertorum extract; $(\square)$ : Ascorbic acid

TABLE 2: ANTIBACTERIAL ACTIVITY OF ETHANOLIC EXTRACT OF F. desertorum

\begin{tabular}{|c|c|c|c|c|c|}
\hline \multirow{3}{*}{ Bacteria strains } & \multicolumn{5}{|c|}{ Zone of inhibition $(\mathrm{mm})$} \\
\hline & \multicolumn{4}{|c|}{ F. desertorum extract concentrations } & \multirow{2}{*}{$\begin{array}{c}\text { Levoflaxcine } \\
1 \mathrm{mg} / \mathrm{ml}\end{array}$} \\
\hline & $10 \mathrm{mg} / \mathrm{ml}$ & $20 \mathrm{mg} / \mathrm{ml}$ & $30 \mathrm{mg} / \mathrm{ml}$ & $40 \mathrm{mg} / \mathrm{ml}$ & \\
\hline Staphylococcus aureus & - & - & 6 & 10 & 25 \\
\hline Proteus vulgaris & - & - & 5 & 6 & 11 \\
\hline Micrococcus luteus & 4 & 5 & 8 & 9 & 10 \\
\hline Klebsela pneumonia & - & 5 & 6 & 7 & 25 \\
\hline
\end{tabular}


Elemental analysis of $F$. desertorum showed that the $\mathrm{Na}(92.936 \mathrm{mg} / \mathrm{ml})$ was found to be present in large amount while zinc $(0.060 \mathrm{mg} / \mathrm{g})$ was present in low concentration but cobalt was not detected. The distribution levels of the elements analyzed and quantified in the present study follows the order $\mathrm{Na}>\mathrm{Ca}>\mathrm{Mg}>\mathrm{Cr}>\mathrm{Fe}>\mathrm{Mn}>\mathrm{Cd}>\mathrm{Cu}>\mathrm{Zn}$. The elemental analysis of $F$. desertorum showed variation among different elements concentration (Table 4).

F. desertorum extract evaluated to show good brine shrimp lethality activity. In the present study, extract toxicity was found to be concentration dependent manner. Higher toxicity was recorded for high concentrations of the plant extracts and the degree of toxicity was found to be directly proportional to the concentration of the extract. Maximum mortalities (70\%) took place at the concentration of $250 \mu \mathrm{g} / \mathrm{ml}$ and least mortalities $(30 \%)$ were at $50 \mu \mathrm{g} / \mathrm{ml}$ concentration with $\mathrm{IC}_{50}$ value $127.00 \mu \mathrm{g} / \mathrm{ml}$ (Table 5).
Nature is a rich source of medical metabolites and some of them are found in plants. Extracts, which are rich in flavonoid metabolites, through decreasing oxidative stress, protect cells ${ }^{[31]}$. Phenols and polyphenols are found in many foods and have great antioxidant effects $^{[32]}$. The extract of $F$. desertorum seems to be reactive against DPPH, ABTS and $\mathrm{H}_{2} \mathrm{O}_{2}$ free radicals. The ethanolic extract also showed a maximum total antioxidant and reducing power activity. The $\mathrm{IC}_{50}$ value was calculated which was different in all the activities (Table 1). The lower $\mathrm{IC}_{50}$ value of the plant extract showed remarkable antioxidant activity. Our results showed that the antioxidant activity may be due to presences of phenol and flavonoid compounds. The results are following the results of Kanatt ${ }^{[33]}$ to reported mint (Mentha) extract have many phenol (caffeic, p-coumaric, ferulic and neo chlorogenic) and flavonoid compounds (quercetin, luteolin, apigenin, kaempferol and isorhamnetin and Myricetin) and shows a good antioxidative activity. Shukla ${ }^{[34]}$ reported that strong

TABLE 3: ANTIFUNGAL ACTIVITY OF F. desertorum ETHANOLIC EXTRACT

\begin{tabular}{lcccc}
\hline \multirow{2}{*}{ Treatment } & \multicolumn{4}{c}{ Percent inhibition of mycelia growth } \\
\cline { 2 - 5 } & \multicolumn{1}{c}{ Concentration $(\mathrm{mg} / \mathrm{ml})$} & Aspergillus niger & Aspergillus flavus & Aspergillus fumigatus \\
\hline Terbinofine (positive & 1 & 100 & 100 & 100 \\
control) & 10 & 20 & 40 & 70 \\
& 20 & 60 & 70 & 80 \\
F. desertorum extract & 30 & 70 & 80 & 90 \\
& & & & 90 \\
\hline
\end{tabular}

TABLE 4: ELEMENTAL ANALYSIS OF $F$. desertorum WHOLE PLANT

\begin{tabular}{lcc}
\hline Sample & Elements $(\mathrm{mg} / \mathrm{g})$ & Concentration $(\mathrm{mg} / \mathrm{g}$ dry weight of sample) \\
\hline & $\mathrm{Mg}$ & $92.936 \pm 0.804(\mathrm{C})$ \\
$\mathrm{Ca}$ & $\mathrm{Cr}$ & $93.780 \pm 0.677(\mathrm{~B})$ \\
$\mathrm{Mn}$ & $\mathrm{Co}$ & $2.373 \pm 0.012(\mathrm{D})$ \\
& $\mathrm{Zn}$ & $0.420 \pm 0.016(\mathrm{E})$ \\
& $\mathrm{Cd}$ & Not detected \\
& $\mathrm{Cu}$ & $0.060 \pm 0.0089(\mathrm{E})$ \\
& $\mathrm{Fe}$ & $0.080 \pm 0.008(\mathrm{E})$ \\
& $\mathrm{Na}$ & $0.070 \pm 0.008(\mathrm{E})$ \\
& & $1.873 \pm 0.012(\mathrm{D})$ \\
\end{tabular}

TABLE 5: CYTOTOXICITY ACTIVITY OF F. desertorum ETHANOLIC EXTRACT

\begin{tabular}{lccccc}
\hline $\begin{array}{l}\text { Plant extract } \\
\text { concentrations }(\mu \mathrm{g} / \mathrm{ml})\end{array}$ & $\begin{array}{c}\text { Total number of } \\
\text { Shrimps }\end{array}$ & $\begin{array}{c}\text { Total Number of } \\
\text { survival shrimps }\end{array}$ & $\begin{array}{c}\text { Total number of } \\
\text { Dead shrimps }\end{array}$ & $\begin{array}{c}\text { Percent }(\%) \\
\text { Mortality }\end{array}$ & LC $_{50}(\mu \mathrm{g} / \mathrm{ml})$ \\
\hline 50 & 10 & $7 \pm 0.000(\mathrm{~A})$ & $3 \pm 0.000(\mathrm{C})$ & 30 & \\
100 & 10 & $6 \pm 0.000(\mathrm{~A})$ & $4 \pm 0.000(\mathrm{C})$ & 40 & 127 \\
150 & 10 & $4.67 \pm 0.471(\mathrm{~B})$ & $5.33 \pm 0.471(\mathrm{~B})$ & 53 & 60 \\
200 & 10 & $4 \pm 0.816(\mathrm{BC})$ & $6 \pm 0.816(\mathrm{AB})$ & 70 & \\
250 & 10 & $3 \pm 0.816(\mathrm{C})$ & $7 \pm 0.816(\mathrm{~A})$ & 70 & \\
\hline
\end{tabular}


antioxidative activity of extracts is related to the high levels of existing phenols and flavonoids in extracts. Wojdyło et al. ${ }^{[35]}$ identified major phenolic acids in 32 species were caffeic, p-coumaric, ferulic and neo chlorogenic, while predominant flavonoids were quercetin, luteolin, apigenin, kaempferol, isorhamnetin and Myricetin and reported that had high levels of phenolics and flavonoids exhibited high antioxidant capacity.

The antifungal and antibacterial activity of the medicinal plant extract is due to the presence of phenolic compounds within the extracts ${ }^{[36]}$. Table 2 shows that $F$. desertorum plant extract had considerable activity against Proteus vulgaris, Micrococcus luteus, Klebsiella pneumonia and Staphylococcus aureus. Our results are in close connection with results of Phyllanthus niruri extract ${ }^{[37]}$, Piper betel Linn leaf ${ }^{[38]}$ and Pinus sylvestris ${ }^{[39]}$. F. desertorum extracts exhibiting remarkable antibacterial activity, which may be due to the presence of phenolic compounds (quercetin, caffeic acid, coumaric acid, tannic acid and catechin), alkaloids (Squalamine, Lysergol, Tetrandrine and Tomatidine) and flavonoids (apigenin, galangin, flavone and flavonol glycosides, isoflavones, flavanones and chalcones). Our result is following the results of Tyagi ${ }^{[40]}$ reported that phenolic compounds like quercetin, caffeic acid, coumaric acid, tannic acid and catechol were effective in inhibiting the growth of the bacteria. Cushnie et al. ${ }^{[41]}$ reported that alkaloids (Squalamine, Lysergol, Tetrandrine and Tomatidine) possess antibacterial activity. Cushnie et al. ${ }^{[42]}$ reported several flavonoids including apigenin, galangin, flavone and flavonol glycosides, isoflavones, flavanones and chalcones have been shown to possess potent antibacterial activity. Saponins are also stood responsible for their antifungal activity ${ }^{[43]}$. The antifungal activity (Table 3) showed the plant extract inhibiting potential against Aspergillus fumigatus, Aspergillus niger and Aspergillus flavus. The antifungal activity of the extract may be due to saponins (a-tomatine and avenacin) and our result showed the similarity with the result of Mert-Türk et $a l .{ }^{[44]}$ investigated that saponins (a-tomatine and avenacin) have potential antifungal activity.

The importance of mineral in maintaining human and plant well-being cannot be denied since their role is supposed to be crucial ${ }^{[45,46]}$. It was found that plant extract contains a good amount of certain mineral including $\mathrm{Mg}, \mathrm{Ca}, \mathrm{Cr}, \mathrm{Mn}, \mathrm{Co}, \mathrm{Zn}, \mathrm{Cd}, \mathrm{Cu}, \mathrm{Fe}$ and $\mathrm{Na}$.
These results are inconsistency with the one reported on the elemental analysis of Bryonia alba root extract ${ }^{[47]}$.

To test the cytotoxicity potential of medicinal plants, brine shrimp's lethality assay plays an important role because the assay is low cost and easy to handle ${ }^{[16]}$. Plants showing cytotoxicity on shrimps could possess significant wonderful anti-cancer activity ${ }^{[48]}$. The plant extract showed a significant cytotoxic effect in vitro due to presence of secondary metabolites ${ }^{[49,50]}$. The present results showed that the extract possesses potential anticancer activity which might due to the presence of quercetin. The $\mathrm{LC}_{50}$ value of the extract was found to be $127 \mu \mathrm{g} / \mathrm{ml}$. Our results are following the result of Markaverich et al.$^{[51]}$ to propose that quercetin possess anticancer activity. These results are significant and present the plant extract for isolation of active metabolites, designing and synthesis of new drugs.

In conclusion the results of present study reveal that elemental analysis of $F$. desertorum extract showed the presence of $\mathrm{Na}, \mathrm{Fe}, \mathrm{Cu}, \mathrm{Cd}, \mathrm{Zn}, \mathrm{Mn}, \mathrm{Cr}, \mathrm{Ca}$ and $\mathrm{Mg}$. The consumption of this plant may therefore have many benefits to human health. Owing to the availably of a substantial quantity of minerals the plant of $F$. desertorum may be used as a dietary supplement. The plant also exhibited the inhibitory, antimicrobial and cytotoxicity activities in a concentration-dependent manner. The results of the present study suggest that the ethanol extract of $F$. desertorum can be used as a prospective source of natural antioxidant, antimicrobial and anti-cancer/anti-tumor agents. Further studies are recommended to design and synthesize useful drugs after isolation of active ingredients within the plant extract.

\section{Acknowledgements:}

The authors acknowledge their profound gratitude to the Department of Botany, Chemistry and Biotechnology of the University of Science and Technology Bannu for supporting and providing all the facilities to conduct the research work.

\section{Conflict of interests:}

The authors declared no conflicts of interest.

\section{REFERENCES}

1. Akerele, Olayiwola, Heywood, Vernon H, Synge, Hugh, et al. The Conservation of medicinal plants: proceedings of an international consultation. Cambridge University Press, UK; 1991. p. 25-51.

2. General guidelines for methodologies on research and evaluation of traditional medicines. World Health Organization, 
Geneva 2000:1-70.

3. Dimayuga RE, Garcia SK. Antimicrobial screening of medicinal plants from Baja California Sur, Mexico. J Ethnopharmacol 1991;31(2):181-92.

4. Craig WJ. Health-promoting properties of common herbs. Am J Clin Nutr 1999;70(3):491-9.

5. Shinwari ZK. Medicinal plants research in Pakistan. J Med Plant Res 2010;4(3):161-76.

6. Lai LS, Chou ST, Chao WW. Studies on the antioxidative activities of Hsian-tsao (Mesona procumbens Hemsl) leaf gum. J Agri Food Chem 2001;49(2):963-8.

7. Tachakittirungrod S, Okonogi S, Chowwanapoonpohn S. Study on antioxidant activity of certain plants in Thailand: Mechanism of antioxidant action of guava leaf extract. Food Chem 2007;103(2):381-8.

8. Javanmardi J, Stushnoff C, Locke E, Vivanco JM. Antioxidant activity and total phenolic content of Iranian Ocimum accessions. Food Chem 2003;83(4):547-50.

9. Pitocco D, Zaccardi F, Di Stasio E, Romitelli F, Santini SA, Zuppi C, et al. Oxidative stress, nitric oxide and diabetes. Rev Diabet Stud 2010;7(1):15-25.

10. Soylu EM, Tok FM, Soylu S, Kaya AD, Evrendilek GA. Antifungal activities of essential oils on postharvest disease agent Penicillium digitatum. Pak J Biol Sci 2005;8:25-9.

11. Lee CK, Kim H, Moon KH, Shin KH. Screening and isolation of antibiotic resistance inhibitors from herb materials-resistance inhibition of volatile components of Korean aromatic herbs. Arch Pharma Res 1998;21(1):62-6.

12. Natarajan V, Venugopal PV, Menon T. Effect of Azadirachta indica (neem) on the growth pattern of dermatophytes. Ind $\mathrm{J}$ Med Microbiol 2003;21(2):98-101.

13. Araújo CR, Miranda KC, Fernandes OD, Soares AJ, Silva MD. In vitro susceptibility testing of dermatophytes isolated in Goiania, Brazil, against five antifungal agents by broth microdilution method. Rev Inst Med Trop Sao Paulo 2009;51(1):9-12.

14. Kaneez FA, Qadirrudin M, Kalhoro MA, Khaula S, Badar Y. Determination of major trace elements in Artemisia elegantissima and Rhazya stricta and their uses. Pak J Sci Ind Res 1998;45:291-3.

15. Bamiro FO, Esuoso KO, Tairu OA. Comparative elemental contents $(\mathrm{Cu}, \mathrm{Ca}, \mathrm{Zn}, \mathrm{K}, \mathrm{Mg}, \mathrm{Ni}, \mathrm{Fe}$ and $\mathrm{Cd})$ of seven various edible tubers in Nigeria. Pak J Sci Ind Res 1995;38:316-8.

16. Meyer BN, Ferrigni NR, Putnam JE, Jacobsen LB, Nichols DJ, McLaughlin JL. Brine shrimp: a convenient general bioassay for active plant constituents. Planta Med 1982;45(5):31-4.

17. Teng WS. Toxicity testing using the brine shrimp: Artemia salina. Bioactive natural products. Detection, isolation and structural determination 1993:441-56.

18. Cassini. Alexander Henri Gabriel de. Bulletin des Science, par la Societe Philomatique, French; 1819. p. 142-3.

19. Brand-Williams W, Cuvelier ME, Berset CL. Use of a free radical method to evaluate antioxidant activity. LWT Food Sci Technol 1995;28(1):25-30.

20. Re R, Pellegrini N, Proteggente A, Pannala A, Yang M, RiceEvans C. Antioxidant activity applying an improved ABTS radical cation decolorization assay. Free Rad Biol Med 1999;26(9-10):1231-7.

21. Umamaheswari $\mathrm{M}$, Chatterjee TK. In vitro antioxidant activities of the fractions of Coccinia grandis L. leaf extract. Afr J Tradit Complement Alternat Med 2008;5(1):61-73.

22. Ruch RJ, Cheng SJ, Klaunig JE. Prevention of cytotoxicity and inhibition of intercellular communication by antioxidant catechins isolated from Chinese green tea. Carcinogenesis 1989;10(6):1003-8.

23. Oyaizu M. Antioxidant activity of browning products of glucosamine fractionated by organic solvent and thin-layer chromatography. J Japan Soc Food Sci Technol 1986;35:7715.

24. Khalil AT, Khan I, Ahmad K, Khan YA, Khan J, Shinwari ZK. Antibacterial activity of honey in north-west Pakistan against select human pathogens. J Tradit Chin Med 2014;34(1):86-9.

25. Ahmad B, Ali N, Bashir S, Choudhary MI, Azam S, Khan I. Parasiticidal, antifungal and antibacterial activities of Onosma griffithii Vatke. Afr J Biotechnol 2009;8(19):5084-7.

26. Hseu ZY. Evaluating heavy metal contents in nine composts using four digestion methods. Biores Technol 2004;95(1):539.

27. Eslami A, Khaniki GR, Nurani M, Mehrasbi M, Peyda M, Azimi R. Heavy metals in edible green vegetables grown along the sites of the Zanjanrood river in Zanjan, Iran. J Biol Sci 2007;7(6):943-8.

28. Saeed M, Khan H, Khan MA, Khan F, Khan SA, Muhammad N. Quantification of various metals and cytotoxic profile of aerial parts of Polygonatum verticillatum. Pak J Bot 2010;42(6):3995-4002.

29. Meyer-Alber A, Hartmann H, Stümpel F, Creutzfeldt W. Mechanism of insulin resistance in CC14-induced cirrhosis of rats. Gastroenterol 1992;102(1):223-9.

30. Finney DJ. Probit analysis. 3rd ed. Cambridge University Press: Cambridge, UK; 1971.

31. Maher P, Hanneken A. Flavonoids protect retinal ganglion cells from oxidative stress-induced death. Invest Ophthalmol Vis Sci 2005;46(12):4796-803.

32. Bouayed J, Hoffmann L, Bohn T. Total phenolics, flavonoids, anthocyanins and antioxidant activity following simulated gastro-intestinal digestion and dialysis of apple varieties: Bioaccessibility and potential uptake. Food Chem 2011;128(1):14-21.

33. Kanatt SR, Chander R, Sharma A. Antioxidant potential of mint (Mentha spicata $\mathrm{L}$.) in radiation-processed lamb meat. Food Chem 2007;100(2):451-8.

34. Shukla S, Mehta A, Bajpai VK, Shukla S. In vitro antioxidant activity and total phenolic content of ethanolic leaf extract of Stevia rebaudiana Bert. Food Chem Toxicol 2009;47(9):233843.

35. Wojdyło A, Oszmiański J, Czemerys R. Antioxidant activity and phenolic compounds in 32 selected herbs. Food Chem 2007;105(3):940-9.

36. Baydar NG, Özkan G, Sağdiç O. Total phenolic contents and antibacterial activities of grape (Vitis vinifera L.) extracts. Food Control 2004;15(5):335-9.

37. Bokarey M, Thakre P, Wadhai V. Antibacterial activity and phytochemical analysis of Phyllanthus niruri against common human pathogenic bacteria. Rev Res 2012;1(6):30.

38. Datta A, Ghoshdastidar S, Singh M. Antimicrobial property of Piper betel leaf against clinical isolates of bacteria. Int J Pharma Sci Res 2011;2(3):104-9.

39. Czerwińska E, Szparaga A. Antibacterial and antifungal activity of plant extracts. Yearbook Environmental Protection 2015;17(1):209-29.

40. Tyagi B, Dubey A, Verma A, Tiwari S. Antibacterial activity of phenolics compounds against pathogenic bacteria. Int J Pharm Sci Rev Res 2015;35(1):16-8.

41. Cushnie TT, Cushnie B, Lamb AJ. Alkaloids: An overview of their antibacterial, antibiotic-enhancing and antivirulence 
activities. Int J Antimicrob Agents 2014;44(5):377-86.

42. Cushnie T, Lamb AJ. Antimicrobial activity of flavonoids. Int J Antimicrob Agents 2005;26(5):343-56.

43. Mothana RA, Gruenert R, Lindequist U, Bednarski PJ. Study of the anticancer potential of Yemeni plants used in folk medicine. Pharmazie 2007;62(4):305-7.

44. Mert-Türk F. Saponins versus plant fungal pathogens. J Cell Mol Biol 2006;5:13-7.

45. Pytlakowska K, Kita A, Janoska P, Połowniak M, Kozik V. Multi-element analysis of mineral and trace elements in medicinal herbs and their infusions. Food Chem 2012;135(2):494-501.

46. Jabeen S, Shah MT, Khan S, Hayat MQ. Determination of major and trace elements in ten important folk therapeutic plants of Haripur basin, Pakistan. J Med Plants Res 2010;4(7):559-66.

47. Karpiuk UV, Al Azzam KM, Abudayeh ZH, Kislichenko V, Naddaf A, Cholak I, et al. Qualitative and quantitative content determination of macro-minor elements in Bryonia alba L. roots using flame atomic absorption spectroscopy technique.
Adv Pharma Bull 2016;6(2):285-91.

48. Ramachandran S, Vamsikrishna M, Gowthami KV, Heera B, Dhanaraju MD. Assessment of cytotoxic activity of Agave cantula using brine shrimp (Artemia salina) lethality bioassay. Asian J Sci Res 2011;4(1):90-4.

49. Krishnaraju AV, Rao TV, Sundararaju D, Vanisree M, Tsay HS, Subbaraju GV. Assessment of bioactivity of Indian medicinal plants using brine shrimp (Artemia salina) lethality assay. Int $\mathrm{J}$ Appl Sci Eng 2005;3(2):125-34.

50. Punitha D, Thandavamoorthy A, Arumugasamy K, Danya $\mathrm{U}$, Udhayasankar MR, Baluprakash $\mathrm{T}$, et al. Potent in vitro Cytotoxic Effect of Gmelina arborea Roxb.(Verbenaceae) on Three Human Cancer Cell lines. Int J Pharm Sci Res 2012;3(4):357-63.

51. Markaverich BM, Roberts RR, Alejandro MA, Johnson GA, Middleditch BS, Clark JH. Bioflavonoid interaction with rat uterine type II binding sites and cell growth inhibition. J Steroid Biochem 1988;30(1-6):71-8. 